\title{
Tumour-infiltrating lymphocytes predict for outcome in HPV-positive oropharyngeal cancer
}

M J Ward ${ }^{1,2}$, S M Thirdborough ${ }^{1}$, T Mellows ${ }^{1}, \mathrm{C} \mathrm{Riley}^{1}, \mathrm{~S} \mathrm{Harris}^{3}, \mathrm{~K} \mathrm{Suchak}^{4}$, A Webb ${ }^{5}, \mathrm{C} \mathrm{Hampton}^{6}$, N N Patel ${ }^{2}$, C J Randall ${ }^{2}$, H J Cox ${ }^{7}$, S Jogai ${ }^{8}$, J Primrose ${ }^{9}$, K Piper $^{4}$, C H Ottensmeier ${ }^{1,10}$, E V King ${ }^{1,7,10,11}$ and G J Thomas ${ }^{*}, 1,8,10,11$

${ }^{1}$ Cancer Sciences Unit, Faculty of Medicine, University of Southampton, Tremona Road, Southampton SO16 6YD, UK; ${ }^{2}$ Department of Otolaryngology_-Head and Neck Surgery, University Hospital Southampton NHS Foundation Trust, Tremona Road, Southampton SO16 6YD, UK; ${ }^{3}$ Department of Medical Statistics, University of Southampton, Tremona Road, Southampton SO16 6YD, UK; ${ }^{4}$ Department of Cellular Pathology, Bart's and The London School of Medicine and Dentistry, Garrod Building, Turner Street, Whitechapel, London E1 2AD, UK; ${ }^{5}$ Department of Oral and Maxillofacial Surgery, University Hospital Southampton NHS Foundation Trust, Tremona Road, Southampton SO16 6YD, UK; ${ }^{6}$ Macmillan Head, Neck and Thyroid Specialist Nurse Team, University Hospital Southampton NHS Foundation Trust, Tremona Road, Southampton SO16 6YD, UK; ${ }^{7}$ Department of Otolaryngology_-Head and Neck Surgery, Poole NHS Foundation Trust, Longfleet Road, Poole BH15 2JB, UK; ${ }^{8}$ Department of Cellular Pathology, University Hospital Southampton NHS Foundation Trust, Tremona Road, Southampton SO16 6YD, UK; ${ }^{9}$ Department of Surgery, University Hospital Southampton NHS Foundation Trust, Tremona Road, Southampton SO16 6YD, UK and ${ }^{10}$ NIHR Experimental Cancer Medicine Centre Southampton, Tremona Road, Southampton SO16 6YD, UK

Background: Human papillomavirus (HPV)-positive oropharyngeal cancer (OPSCC) is associated with improved survival compared with HPV-negative disease. However, a minority of HPV-positive patients have poor prognosis. Currently, there is no generally accepted strategy for identifying these patients.

Methods: We retrospectively analysed 270 consecutively treated OPSCC patients from three centres for effects of clinical, pathological, immunological, and molecular features on disease mortality. We used Cox regression to examine associations between factors and OPSCC death, and developed a prognostic model for 3-year mortality using logistic regression analysis.

Results: Patients with HPV-positive tumours showed improved survival (hazard ratio (HR), 0.33 (0.21-0.53)). High levels of tumourinfiltrating lymphocytes (TILs) stratified HPV-positive patients into high-risk and low-risk groups (3-year survival; HPV-positive/ $\mathrm{TIL}_{\text {high }}=96 \%$, HPV-positive/TIL low $=59 \%$ ). Survival of HPV-positive/TIL low patients did not differ from HPV-negative patients (HR, 1.01; $P=0.98)$. We developed a prognostic model for HPV-positive tumours using a 'training' cohort from one centre; the combination of TIL levels, heavy smoking, and T-stage were significant (AUROC $=0 \cdot 87$ ). This model was validated on patients from the other centres (detection rate 67\%; false-positive rate $5.6 \%$; $A U R O C=0 \cdot 82$ ).

Interpretation: Our data suggest that an immune response, reflected by TIL levels in the primary tumour, has an important role in the improved survival seen in most HPV-positive patients, and is relevant for the clinical evaluation of HPV-positive OPSCC.

\footnotetext{
*Correspondence: Dr GJ Thomas; E-mail: g.thomas@soton.ac.uk

${ }^{11}$ These authors contributed equally to this work.
}

Received 7 June 2013; revised 28 August 2013; accepted 12 September 2013; published online 29 October 2013 
Human papillomavirus (HPV) is the primary cause of oropharyngeal cancer (OPSCC), accounting for $40-80 \%$ of cases in the western world (D'Souza et al, 2007; Termine et al, 2008; Adelstein et al, 2009; Dayyani et al, 2010). The incidence of HPV-associated OPSCC has increased significantly over the past 40 years, and continues to rise (Adelstein et al, 2009; Chaturvedi et al, 2011).

$\mathrm{HPV}$-associated OPSCC commonly presents at advanced stage and is usually poorly differentiated (Adelstein et al, 2009; Sethi et al, 2012). Although both factors would be expected to result in poor outcomes, studies report significantly better long-term survival in most HPV-positive OPSCC patients compared with those with HPV-negative disease of matched stage (Licitra et al, 2006; Fakhry et al, 2008; Worden et al, 2008; Lassen et al, 2009; Ang et al, 2010; Dayyani et al, 2010). The explanation for this remains unclear and may be multifactorial. Human papillomavirus-positive tumours have improved response to chemotherapy/ radiotherapy compared with HPV-negative tumours, possibly modulated through the expression of wild-type p53 and $\mathrm{Rb}$ tumour suppressor genes; patients with HPV-positive cancers have a lower risk of developing secondary primary tumours, probably due to the absence of field cancerisation; in addition, HPV status inversely correlates with biomarkers of poor prognosis such as EGFR (Westra et al, 2008; Adelstein et al, 2009; Hong et al, 2010a).

A potential explanation for survival benefit may be that tumourinfiltrating T lymphocytes (TILs), which permeate many HPV-positive OPSCC, confer a protective effect through an adaptive host immune response directed against viral antigens, and HPV-16 E7-specific T cells have been reported in OPSCC patients (Albers et al, 2005; Wansom et al, 2010, 2012). Although TIL abundance is associated with improved clinical outcomes in a number of other tumour types, their role in head and neck malignancy is not well documented (Galon et al, 2006; Uppaluri et al, 2008; Gooden et al, 2011).

Several studies have reported that the survival advantage of HPV-driven tumours is independent of treatment modality, whether surgery, radiation, or chemoradiotherapy (or combinations thereof), raising the possibility that some HPV-positive patients receive unnecessary treatment (Licitra et al, 2006; Fakhry et al, 2008; Adelstein et al, 2009; Lassen et al, 2009; Ang et al, 2010; Hong et al, 2010b). This has led to suggestions that treatment be de-intensified to reduce therapy-related morbidity (Adelstein et al, 2009), and a number of clinical trials are testing this currently. However, within the HPV-positive OPSCC population, there remains a significant minority that respond poorly to treatment and have a poor prognosis. Ang et al (2010) identified three different 'at-risk' groups for patients with oropharyngeal cancer and found that HPV-positive patients who were heavy smokers and had advanced nodal disease ( $>10$ pack-years smoking with N2b disease or above) were at an 'intermediate' risk of death. These factors have subsequently been validated independently and have been used as exclusion criteria in some de-escalation trials (Ang et al, 2010; Granata et al, 2012). Other authors have also described an association between heavy smoking and poor outcome in patients with HPV-positive tumours (Adelstein et al, 2009; Gillison et al, 2012; Sethi et al, 2012); however, there is still no widely accepted strategy for identifying high-risk HPV-positive patients.

In this study, we assess the relative contributions of HPV status and pathological, molecular, and immunological features in survival from OPSCC. We correlate them with known clinical predictors of outcome to formulate a predictive tool for OPSCC patients with the ultimate aim of facilitating stratification of patients for treatment decisions.

\section{PATIENTS AND METHODS}

We retrospectively identified 442 consecutively treated patients with OPSCC (University Hospital Southampton (UHS; 2000-2010), $n=316$; Poole NHS Foundation Trust and Bart's and the London NHS Trust (PFT/BLT; 2000-2006), $n=126$. Patients were excluded from further analysis if they had follow-up of $<6$ months, had received either no treatment or treatment without curative intent, or had an unknown cause of death. Following these exclusions, 402 patients remained. Archived pathology material was available for 274 patients who were subsequently analysed further. Demographics and survival of patients without pathology material were comparable to those with pathology material (Supplementary Information). All patients were analysed according to REMARK guidelines (McShane et al, 2005). Data were obtained from patient records on age, sex, site, smoking (non-, ex- (stopped smoking $>6$ months previously), light smokers (defined as <10 pack year history (Ang et al, 2010; Gillison et al, 2012)), heavy smokers (> 10 pack year history)), alcohol (non-/exdrinker, current drinker $>10$ units per week), T stage, $\mathrm{N}$ stage, treatment modality, treatment failure, tumour recurrence, date, and cause of death. Data on smoking and alcohol consumption can be difficult to accurately obtain in retrospective studies, often because of poor documentation. In this study, smoking data were more accurately recorded in the medical records than alcohol consumption, with reliable data available in $87 \%$ and $74 \%$ of cases, respectively. Demographics are shown in Table 1. Ethical approval was obtained (UKCRN 8130; ISRCTN 71276356; and REC references 09/H0501/90 and 07/Q0405/1).

Treatment. A treatment summary is included in Table 1. The centres involved in this study differed in their approach to treatment of OPSCC, with more patients being surgically treated at UHS. This allowed a direct comparison of survival according to treatment modality. Patients undergoing chemoradiotherapy received 2-6 doses of platinum-based chemotherapy (either cisplatin or carboplatin) combined with $64-66$ Gy of radiotherapy given in 32-33 fractions. No patients received accelerated fractionation or intensity-modulated radiotherapy. Neoadjuvant chemotherapy was 1-2 doses of either cisplatin or carboplatin, in conjunction with 5-flurouracil. Of the surgically treated patients, $78 \%$ received post-operative radiotherapy. Full details are given in Supplementary Information.

Histology and immunochemistry. Tumour histology was reviewed by pathologists (GJT, SJ, and KP) blinded to treatment and outcome, according to the 1998 UK Royal College of Pathologist Guidelines, and a suitable paraffin block was selected. From a haematoxylin/eosin $(\mathrm{H}+\mathrm{E})$-stained section, data were obtained on grade (well, moderate, or poorly differentiated). A prominent lymphocytic infiltrate (TIL) was scored under low-power magnification $(\times 2 \cdot 5$ objective) as high (diffuse; present in $>80 \%$ of tumour/stroma), low (weak/absent; present in $<20 \%$ of tumour/stroma), or moderate (patchy; present in $20-80 \%$ of tumour/stroma) as described (Marsh et al, 2011). Concordance between pathologists in identifying $\mathrm{TIL}_{\text {low }}$ tumours was $>95 \%$. Typical examples of $\mathrm{TIL}_{\text {high }}$ and $\mathrm{TIL}_{\text {low }}$ tumours are shown in Figure 1D and Supplementary Information.

Tissue microarrays (TMAs) were constructed using triplicate, randomly selected, paraffin-embedded 1-mm tumour cores (Aphelys Minicore 2, Mitogen, Harpenden, UK). Automated immunostaining (Ventana XT, Ventana, Tucson, AZ, USA) was performed in a CPA-accredited clinical cellular pathology department using antibodies optimised to national diagnostic standards (NEQAS). The antigenic targets were as follows: p16 (CINtec, Roche, Burgess Hill, UK), EGFR (Dako, Ely, UK), T-lymphocyte markers (CD3, pan T cells; CD4, helper T cells; CD8, cytotoxic T cells (all from Novocastra, Milton Keynes, UK); FoxP3, regulatory $\mathrm{T}$ cells (eBioscience, Hatfield, UK), and B lymphocytes (CD20) (Novocastra). TILs were quantified using a Zeiss AxioCam MRc5 microscope (Zeiss, Cambridge, UK) and Zeiss Axiovision software (version $4 \cdot 8 \cdot 1 \cdot 0$ ) (Zeiss). An average intratumoural TIL 
Table 1. Baseline characteristics of patients in the retrospective patient cohorts (i.e., at the time of diagnosis)

\begin{tabular}{|c|c|c|c|}
\hline & $\begin{array}{c}\text { All OPSCC } \\
n=274 \\
\text { Number (\%) }\end{array}$ & $\begin{array}{c}\text { HPV-positive OPSCC } \\
n=149 \\
\text { Number (\%) }\end{array}$ & $\begin{array}{c}\text { HPV-negative OPSCC } \\
n=121 \\
\text { Number (\%) }\end{array}$ \\
\hline \multicolumn{4}{|l|}{ Gender } \\
\hline $\begin{array}{l}\text { Male } \\
\text { Female }\end{array}$ & $\begin{array}{r}200(73.0) \\
74(27.0)\end{array}$ & $\begin{array}{r}111(74.5) \\
38(25.5)\end{array}$ & $\begin{array}{l}86(71.1) \\
35(28.9)\end{array}$ \\
\hline \multicolumn{4}{|l|}{ Age at diagnosis (years) } \\
\hline $\begin{array}{l}<50 \\
50-69 \\
70+ \\
\text { Mean (s.d.) }\end{array}$ & $\begin{array}{r}58(21.2) \\
168(61.3) \\
48(17.5) \\
58.2(11.2)\end{array}$ & $\begin{array}{r}40(26.8) \\
91(61.1) \\
18(12.1) \\
56.4(10.8)\end{array}$ & $\begin{array}{r}18(14.9) \\
74(61.2) \\
29(24.0) \\
60.4(11.4)\end{array}$ \\
\hline \multicolumn{4}{|l|}{ Smoking } \\
\hline $\begin{array}{l}\text { Non-/ex-smoker } \\
\text { Current }<10 \text { pack-years } \\
\text { Current }>10 \text { pack-years } \\
\text { Not Known }\end{array}$ & $\begin{aligned} & 107(39.1) \\
& 18(6.6) \\
& 114(41.6) \\
& 35(12.8)\end{aligned}$ & $\begin{array}{l}82(55.0) \\
10(6.7) \\
41(27.5) \\
16(10.7)\end{array}$ & $\begin{aligned} & 23(19.0) \\
& 8(6.6) \\
& 72(59.5) \\
& 18(14.9)\end{aligned}$ \\
\hline \multicolumn{4}{|l|}{ Alcohol } \\
\hline $\begin{array}{l}\text { Non-/ex-drinker } \\
\text { Current drinker } \\
\text { Not known }\end{array}$ & $\begin{array}{r}34(12.4) \\
167(60.9) \\
73(26.6)\end{array}$ & $\begin{array}{l}20(13.4) \\
94(63.1) \\
35(23.5)\end{array}$ & $\begin{array}{l}14(11.6) \\
72(59.5) \\
35(28.9)\end{array}$ \\
\hline \multicolumn{4}{|l|}{ Tumour site } \\
\hline $\begin{array}{l}\text { Tonsil } \\
\text { Tongue base } \\
\text { Other oropharynx }\end{array}$ & $\begin{array}{r}158(57.7) \\
70(25.5) \\
46(16.8)\end{array}$ & $\begin{array}{l}99(66.4) \\
40(26.8) \\
10(6.7)\end{array}$ & $\begin{array}{l}57(47.1) \\
28(23.1) \\
36(29.8)\end{array}$ \\
\hline Median length of follow-up in years (range) & $58.0(8-137)$ & $58.5(8-137)$ & $57(8-128)$ \\
\hline \multicolumn{4}{|l|}{ Disease stage } \\
\hline $\begin{array}{l}\text { I/II } \\
\text { III/IV } \\
\text { Not known }\end{array}$ & $\begin{aligned} 53(19.3) \\
219(79.9) \\
2(0.7)\end{aligned}$ & $\begin{aligned} 10 & (6.7) \\
138 & (92.6) \\
1 & (0.7)\end{aligned}$ & $\begin{array}{c}42(34.7) \\
78(64.5) \\
1(0.8)\end{array}$ \\
\hline \multicolumn{4}{|l|}{ T stage } \\
\hline $\begin{array}{l}\text { T1/2 } \\
\text { T3/4 } \\
\text { Not known }\end{array}$ & $\begin{aligned} 187 & (68.2) \\
82 & (29.9) \\
5 & (1.8)\end{aligned}$ & $\begin{aligned} 107 & (71.8) \\
41 & (27.5) \\
1 & (0.7)\end{aligned}$ & $\begin{array}{c}77(63.6) \\
41(33.9) \\
3(2.5)\end{array}$ \\
\hline \multicolumn{4}{|l|}{ Nodal metastases } \\
\hline $\begin{array}{l}\text { No } \\
\text { Yes } \\
\text { Not known }\end{array}$ & $\begin{aligned} 68 & (24.8) \\
204 & (74.5) \\
2 & (0.7)\end{aligned}$ & $\begin{aligned} & 15(10.1) \\
& 133(89.3) \\
& 1\end{aligned}$ & $\begin{array}{c}52(43.0) \\
68(56.2) \\
1(0.8)\end{array}$ \\
\hline \multicolumn{4}{|l|}{$\mathrm{N}$ stage } \\
\hline $\begin{array}{l}\text { N0-N2a } \\
\text { N2b-N3 } \\
\text { Not known }\end{array}$ & $\begin{array}{c}142(51.8) \\
130(47.4) \\
2(0.7)\end{array}$ & $\begin{array}{c}68(45.6) \\
80(53.7) \\
1(0.7)\end{array}$ & $\begin{array}{c}73(60.3) \\
47(38.8) \\
1(0.8)\end{array}$ \\
\hline \multicolumn{4}{|l|}{ Grade } \\
\hline $\begin{array}{l}\text { Well/moderately differentiated } \\
\text { Poorly differentiated }\end{array}$ & $\begin{array}{l}103(37.6) \\
171(62.4)\end{array}$ & $\begin{array}{r}34(22.8) \\
115(77.2)\end{array}$ & $\begin{array}{l}68(56.2) \\
53(43.8)\end{array}$ \\
\hline \multicolumn{4}{|l|}{ Treatment } \\
\hline $\begin{array}{l}\text { Surgery } \pm \text { radiotherapy } \\
\text { Radiotherapy } \\
\text { Chemoradiotherapy }\end{array}$ & $\begin{array}{r}117(42.7) \\
59(21.5) \\
98(35.8)\end{array}$ & $\begin{array}{l}60(40.3) \\
24(16.1) \\
65(43.6)\end{array}$ & $\begin{array}{l}55(45.5) \\
34(28.1) \\
32(26.4)\end{array}$ \\
\hline \multicolumn{4}{|l|}{ TIL status } \\
\hline $\begin{array}{l}\text { Low } \\
\text { Moderate } \\
\text { High } \\
\text { Not known }\end{array}$ & $\begin{aligned} 79 & (28.8) \\
101 & (36.9) \\
92 & (33.6) \\
2 & (0.7)\end{aligned}$ & $\begin{array}{c}22(14.8) \\
53(35.6) \\
72(48.3) \\
2(1.3)\end{array}$ & $\begin{array}{c}56(46.3) \\
46(38.0) \\
19(15.7) \\
0(0.0)\end{array}$ \\
\hline
\end{tabular}




\section{Table 1. (Continued)}

\begin{tabular}{|c|c|c|c|}
\hline & $\begin{array}{c}\text { All OPSCC } \\
n=274 \\
\text { Number (\%) }\end{array}$ & $\begin{array}{c}\text { HPV-positive OPSCC } \\
n=149 \\
\text { Number (\%) }\end{array}$ & $\begin{array}{c}\text { HPV-negative OPSCC } \\
n=121 \\
\text { Number }(\%)\end{array}$ \\
\hline \multicolumn{4}{|c|}{ HPV status } \\
\hline $\begin{array}{l}\text { Negative } \\
\text { Positive } \\
\text { Not known }\end{array}$ & $\begin{array}{c}121(44.2) \\
149(54.4) \\
4(1.5)\end{array}$ & $\begin{array}{l}- \\
- \\
-\end{array}$ & $\begin{array}{l}- \\
- \\
-\end{array}$ \\
\hline \multicolumn{4}{|l|}{ EGFR } \\
\hline $\begin{array}{l}\text { Negative } \\
\text { Positive }\end{array}$ & $\begin{array}{l}108(39.4) \\
166(60.6)\end{array}$ & $\begin{array}{l}77(51.7) \\
72(48.3)\end{array}$ & $\begin{array}{l}29(24.0) \\
92(76.0)\end{array}$ \\
\hline
\end{tabular}

score/high-power field $(\times 400)$ was calculated across representative areas of each triplicate core to allow for intratumoural heterogeneity (i.e., an average of three counts across the tumour). EGFR and p16 were scored as positive ( $>50 \%$ tumour cells positive) or negative ( $\leqslant 50 \%$ tumour cells positive).

In situ hybridisation and HPV classification. HPV in situ hybridisation (ISH) was performed using Genpoint HPV DNA Probe Cocktail (Dako), which recognises the 13 most prevalent high-risk HPV genotypes, including HPV-16 and -18. Cases were scored as negative or positive. Tumours positive both for p16 immunochemistry and HPV ISH were classified as HPV positive (Robinson et al, 2010).

Microarray data analysis. Affymetrix U133 Plus 2.0 CEL files for 46 HNSCC patient samples (24 survivors and 22 non-survivors) were downloaded from a publicly available microarray data set (http://bioinformatics.picr.man.ac.uk/vice/PublicProject.vice?pid=361) and normalised in BioConductor-R (version 2.15.1) (Bioconductor, Seattle, WA, USA). Gene-set enrichment analysis was performed using the GSEA 2.7 software package (Broad Institute of MIT and Harvard, Cambridge, MA, USA). All 15,031 genes differentially expressed between survivors and non-survivors were rank ordered and tested for enrichment of gene sets upregulated during T-cell differentiation (Best et al, 2013).

Statistics. The primary endpoint was death from OPSCC (i.e., disease-specific survival (DSS)). An OPSCC-specific survival time was measured from the date of diagnosis until date of death from OPSCC or date last seen alive. For those that died of other causes, survival from OPSCC was censored at the time of death. Patients in whom the cause of death was unknown, or who received either no treatment or treatment with palliative intent, were excluded from all survival analyses. Kaplan-Meier plots (with log-rank tests) and both unadjusted and adjusted Cox proportional hazards models were used to analyse the survival data. Correlations between factors were assessed by cross-tabulation and the use of either Fisher's exact test or $\chi^{2}$-test where appropriate.

To evaluate the prognostic performance of each factor (i.e., the 3 -year OPSCC death rate), we calculated the detection rate (DR; also known as sensitivity) and false-positive rate (FPR; also known as $1-$ specificity). Detection rate is the proportion of patients who died from OPSCC with marker-positive results; FPR is the proportion of patients who did not die from OPSCC with marker-positive results. Likelihood ratios (DR/FPR) were obtained, which indicate the strength of a marker (i.e., maximising the DR while minimising the FPR; Deeks and Altman, 2004).

A prognostic model for 3-year mortality was developed using binary logistic regression, with a backwards selection procedure (Royston et al, 2009). Variables were retained in the model if they were significant at the $5 \%$ level. The UHS cohort was used as the 'training' set to develop the model, with the PFT/BLT cohort acting as the 'validation' set. A Receiver-operating characteristic (ROC) curve of the linear predictor was used to identify the optimum cut point (balancing both sensitivity and specificity; Royston et al, 2009). The prognostic ability of the final model was then assessed through the calculation of DR and FPR values in the 'validation' set (Heagerty et al, 2000). All statistical tests were two sided and a $P$-value of 0.05 was considered significant. Statistical analyses were performed using SPSS for Windows version 19.0 (IBM, Portsmouth, UK).

\section{RESULTS}

Clinical, pathological, and immunochemical characteristics at the time of diagnosis are shown in Table 1. Human papillomaviruspositive tumours were defined as those positive for both p16 and HPV ISH (Robinson et al, 2010). Similar to previous studies, $94 \%$ of p16-positive cases were HPV ISH positive and $89 \%$ of HPV ISHpositive cases were p16 positive (Robinson et al, 2010).

Of the 274 patients included in the study, 149 (54.4\%) were classified as HPV positive. Human papillomavirus status could not be established in four cases (insufficient tumour tissue remaining in the paraffin block); thus, further analysis was performed on 270 patients (median follow-up 58 months and minimum follow-up 8 months). There were 82 deaths from OPSCC over the study period. Consistent with previous studies, patients with HPV-positive tumours had significantly improved DSS compared with those that were HPV negative (Figure 1A; hazard ratio $(\mathrm{HR})=0.33$ (0.21-0.53)). Table 2A shows the HRs for OPSCC mortality for each factor separately. Improved survival was significantly associated with HPV-positive tumours, a younger age at diagnosis, non-, ex-, or light smokers (defined as $<10$ pack year history (Ang et al, 2010; Gillison et al, 2012)), early T-stage tumours (T1/2), early $\mathrm{N}$-stage tumours $(\mathrm{N} 0-\mathrm{N} 2 \mathrm{a})$, tumours that were EGFR negative, and a high level of TILs (assessed on an $\mathrm{H}+$ E-stained section). When a multivariate analysis was performed (adjusting for age, T stage, $\mathrm{N}$ stage, and smoking status), HPV status and TIL levels remained statistically significant markers of OPSCC mortality (Table 2A).

In unstratified OPSCC, high TIL levels predicted for survival (Figure 1C; Table 2A) and correlated significantly with HPVpositive tumours $(P<0.001)$. The percentage of $\mathrm{HPV}$-positive patients with high, moderate, and low TIL was $49 \%, 36 \%$, and $15 \%$ respectively $(16 \%, 38 \%, 46 \%$, respectively, in HPVnegative tumours). Figure $1 \mathrm{D}$ and $\mathrm{F}$ show typical examples of HPV-positive tumours with high and low TIL levels. 
A

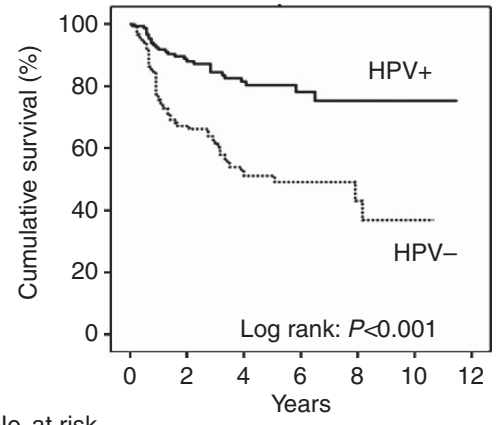

No. at risk

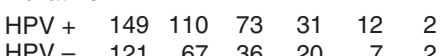

C

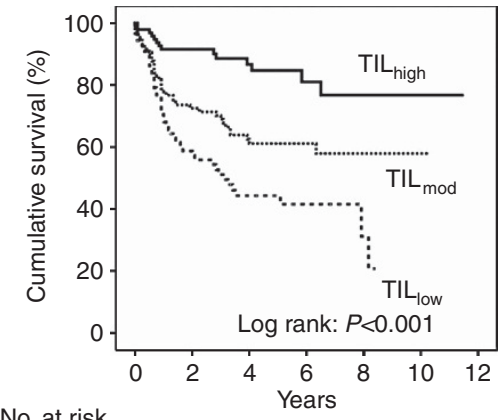

\begin{tabular}{lcccccc} 
No. at risk & \multicolumn{6}{c}{ Years } \\
TIL $_{\text {high }}$ & 92 & 72 & 55 & 21 & 7 & 3 \\
TIL $_{\text {mod }}$ & 101 & 65 & 44 & 18 & 9 & 1 \\
TIL $_{\text {low }}$ & 79 & 41 & 21 & 13 & 3 &
\end{tabular}

E

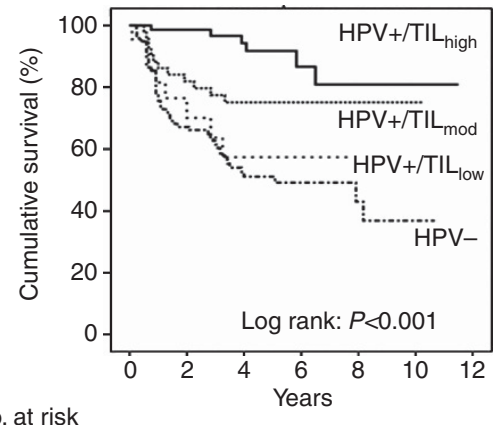

No. at risk

$\begin{array}{lllllll}\mathrm{HPV}+/ \mathrm{TIL}_{\text {high }} & 72 & 59 & 39 & 16 & 5 & 1\end{array}$

$\begin{array}{lllllll}\mathrm{HPV}+/ \mathrm{TIL}_{\bmod } & 53 & 38 & 28 & 11 & 7 & 1\end{array}$

$\begin{array}{lllll}\mathrm{HPV}+/ \mathrm{TIL}_{\text {low }} & 22 & 12 & 6 & 4\end{array}$

$\begin{array}{lllllll}\text { HPV- } & 121 & 67 & 36 & 20 & 7 & 2\end{array}$
B
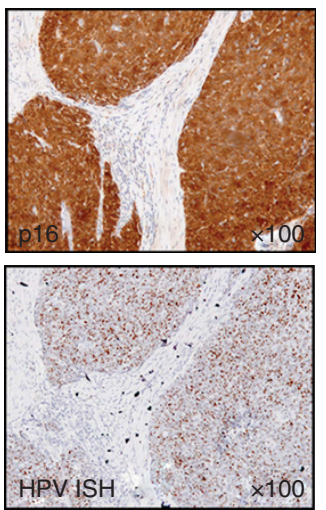

D
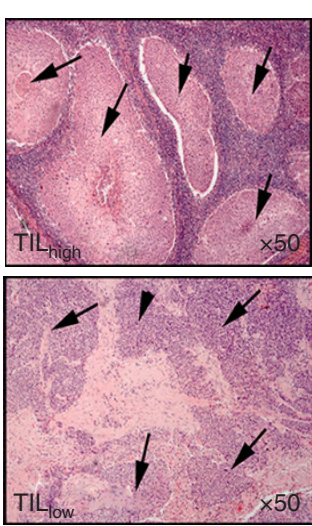

\section{$\mathbf{F}$}
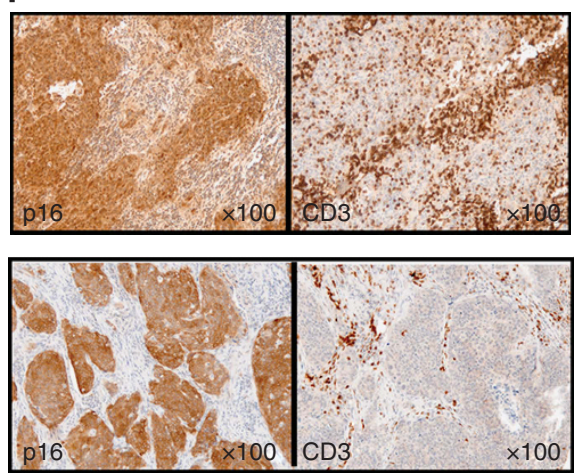

Figure 1. Kaplan-Meier curves for OPSCC mortality in combined patient cohorts. (A) Kaplan-Meier curves for OPSCC mortality according to HPV status (log-rank test, $P<0$.001). (B) Immunochemistry (p16) and ISH (HPV) showing an example of an HPV-positive tumour. (C) Kaplan-Meier curves for OPSCC mortality according to abundance of infiltrating lymphocytes (TIL; high, moderate or low; log-rank test, P<0 • 001). (D) H\&Estained sections showing examples of OPSCC with high and low TIL infiltrates. Tumour islands are arrowed. In TILhigh tumours, lymphocytes fill the stromal compartment and infiltrate into tumour islands. (E) Kaplan-Meier curves for OPSCC mortality stratified according to HPV status and TIL levels. Patients with HPV +/TIL low tumours show similar survival to HPV-negative patients. (F) Immunochemistry showing typical examples of HPVpositive OPSCC with high and low TIL. Tumour is positive for p16, T lymphocytes for CD3.

Demographics of these groups are shown in Supplementary Information.

There was a highly significant difference between the Kaplan-Meier curves for HPV-positive OPSCC DSS according to TIL levels $\left(P<0.001\right.$; Figure 1E); patients with HPV-positive/TIL ${ }_{\text {low }}$ tumours showed similar DSS to HPV-negative patients (Figure 1E) with an adjusted HR of $1.01(P=0.98$; Table 2A). TIL levels predicted similarly for progression-free survival (PFS; log-rank $P<0.001$; data not shown); patients with $\mathrm{HPV}$-positive/TIL low tumours also showed similar PFS to HPV-negative patients with an adjusted HR of $0.64(P=0.23)$. The adjusted HRs for HPV-positive tumours with moderate and high TIL levels indicated a $49 \%$ and $79 \%$ reduction in OPSCC mortality compared with HPV-negative tumours (adjusted HRs, $0 \cdot 51$ and $0 \cdot 21$, respectively; $P=0.17$ and $P=0.02$; Table $2 \mathrm{~B}$ ). In HPV-negative tumours, patients with $\mathrm{TIL}_{\mathrm{high}}$ tumours did not show significantly improved survival (adjusted HR, $0.47, P=0.17$ ) over those with $\mathrm{TIL}_{\text {low }}$ tumours.

Similar to previous studies, we found that heavy smoking reduced survival benefit in HPV-positive patients (HR, 5.81 $(2.38-14.16))$. We therefore assessed whether there was an association between heavy smoking and low TIL levels; low TIL levels did not correlate with heavy smoking ( $>10$ pack-years) and 


\section{Table 2A. HRs for disease-specific death from OPSCC}

\section{All OPSCC $(n=274)$}

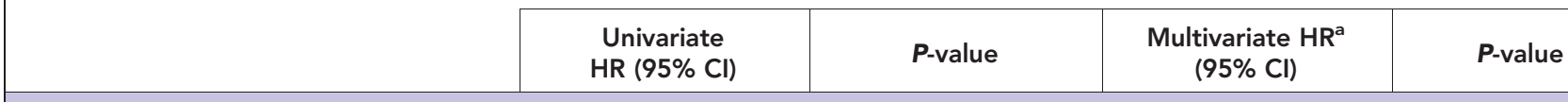

\section{Age}

For each additional year

$1.02(1.00-1.04)$

0.04

$1.03(1.01-1.05)$

0.01

\section{Gender}

Female

Male

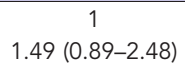

0.13

1
$1.10(0.61-1.96)$

0.75

\section{Smoking}

Non/ex-smoker/current smoker $<10$ pack-years

Current smoker $>10$ pack/years

1

\section{Drinking}

\section{Non/ex-drinker}

Current drinker

$3.24(1.94-5.42)$

$<0.001$

$3.38(2.01-5.70)$

$<0.001$

\section{Stage}

\section{Early (I/II)}

Late (III/IV)

\section{T stage}

$\mathrm{T} 1 / 2$

T3/4

$13 / 4$

Nodal metastases

No
Yes

1

$1.11(0.67-1.84)$

0.68

\subsection{0}

$0.44(0.22-0.88)$

0.02

\section{N stage}

$\mathrm{NO}-\mathrm{N} 2 \mathrm{a}$

$\mathrm{N} 2 \mathrm{~b}-\mathrm{N} 3$

$1.68(1.08-2.60)$

0.02

$1.75(1.07-2.86)$

0.03

\section{Tumour grade}

Well/moderately differentiated Poorly differentiated

$0.80(0.52-1.24)$

\section{Treatment}

\section{Surgery}

Radiotherapy

Chemoradiotherapy

\section{HPV status}

\section{Negative}

Positive

\section{TIL Status}

TIL low

TIL moderate

TIL high

\section{HPV/TIL combined}

HPV -

HPV $+/$ TIL low

$\mathrm{HPV}+/ \mathrm{TIL}$ moderate

HPV + /TIL high

1
$1.53(0.90-2.61)$
$0.95(0.57-1.58)$

$0.95(0.57-1.58)$
0.12

0.83

\section{1}

$1.06(0.56-2.03)$

$0.91(0.51-1.63)$

0.85

0.74

Abbreviations: $\mathrm{Cl}=$ confidence interval; $\mathrm{HPV}=$ human papillomavirus; $\mathrm{HR}=$ hazards ratio; OPSCC= oropharyngeal cancer; $\mathrm{TIL}=$ tumour-infiltrating lymphocyte.

${ }^{a}$ Multivariate analysis adjusted for age, $\mathrm{T}$ stage, $\mathrm{N}$ stage, and smoking status. Patients with no treatment excluded from analysis. 
there was no significant difference in the proportion of $\mathrm{TIL}_{\text {low }}$ tumours according to the amount smoked (percentage of $\mathrm{TIL}_{\mathrm{low}}$ tumours: $<10$ pack year history $14.1 \%,>10$ pack year history $22.5 \%, P=0.15)$.

We performed more complex analysis of the immune infiltrate to establish whether this improved prognostication in HPVpositive tumours. We quantified intratumoural T-lymphocyte number (CD3) and T-cell subsets (CD4, CD8, and Foxp3). We performed ROC analysis (death from OPSCC at 3 years) to determine the predictive value of $\mathrm{T}$-cell number and/or subtype, including subtype ratios (CD4:CD8 and CD8:FoxP3), in comparison with simple $\mathrm{H}+\mathrm{E}$ evaluation of TIL infiltrate. Immunochemical quantification did not outperform the simpler scoring method (Figure 2A and B, and Supplementary Information).

To evaluate whether high TIL levels reflected a bystander or effector response, we tested a publicly available HNSCC microarray data set (Thurlow et al, 2010) for enrichment of gene sets defined as upregulated in naive, effector, or memory $\mathrm{T}$ cells (Best et al, 2013). High expression of gene sets associated with $\mathrm{CD}^{+}$T-cell effector function were significantly enriched (enrichment score $(\mathrm{ES})=0.70, P=0.046$ ) in patients with better survival (Figure 3 and Supplementary Information). Genes upregulated in naive or late memory $\mathrm{CD}^{+} \mathrm{T}$ cells were overrepresented in patients with poor survival but at nonsignificant levels, possibly reflecting their $\mathrm{TIL}_{\text {low }}$ status (ES $=0.30, P=0.46$; data not shown).

Table 3 shows the prognostic performance of each factor (using DR and FPR) for predicting 3-year OPSCC mortality in HPVpositive and HPV-negative patients. Commonly reported prognostic factors are included. In HPV-positive OPSCC, TIL levels were the best-performing factor, with a likelihood ratio (LR) for $\mathrm{TIL}_{\text {low }}$ tumour of 3.3 , followed by heavy smoking and advanced T stage (LR 2.78 and 2.44, respectively). In HPV-negative OPSCC, advancing age, advanced stage, and poor differentiation were the predictive factors with the highest LRs (Table 3 ).

HPV-positive patients had received different types of therapy (cohorts combined: surgery $n=55$, chemoradiotherapy $n=65$, and radiotherapy $n=24$ ). When adjusted for stage and age, there were no significant treatment-dependent survival benefits (HR for DSS relative to surgery: radiotherapy $0.76, P=0.79$ and chemoradiotherapy $1 \cdot 25, P=0.84$ ).

Using the UHS cohort as a training set, we used logistic regression to develop a predictive model for survival from HPVpositive OPSCC (at 3 years). The initial variables entered into the model were as follows: age, $\mathrm{T}$ stage, $\mathrm{N}$ stage, grade, HPV status, TIL level, alcohol history, EGFR, and smoking history. The final model included TIL levels (low $v s$ moderate or high), T stage (T1/2 vs T3/4), and smoking status (heavy vs light-, ex-, or non-smoker). The regression parameter estimates were used to create a prognostic score (equation: $-4.948+2.768$ (if a current heavy smoker $)+2.310\left(\right.$ if $\left.\mathrm{TIL}_{\text {low }}\right)+2.928$ (if T3/4)). ROC analysis was performed and produced an area under the curve of 0.87 (Figure 4A). A cut-off score of -0.945 was selected based on this ROC curve (DR, 72.7\%; FPR 10.2\%; high risk, $n=14$ ) and applied to the PFT/BLT (test; high risk, $n=7$ ) cohort. This score was highly predictive of 3-year mortality, with $66.7 \%$ of dead patients test-positive $(\mathrm{DR}=67 \%)$ and $5.6 \%$ of alive patients testpositive (FPR $=5.6 \%)$. The resultant LR for prediction of 3-year mortality was 11.9 (PFT/BLT, AUROC, 0 82; Figure 4B). Replacing TIL levels with counts or ratios of T-lymphocyte subsets did not improve this model.

\section{DISCUSSION}

Patients with HPV-positive OPSCC have significantly better survival, although the biological reason for this remains unclear
(Adelstein et al, 2009). To reduce therapy-associated morbidity, it may be possible to de-intensify treatment, particularly as several studies have shown survival benefit to be independent of therapy choice (Licitra et al, 2006; Fakhry et al, 2008; Worden et al, 2008; Adelstein et al, 2009; Lassen et al, 2009; Ang et al, 2010; Dayyani et al, 2010; Hong et al, 2010b). However, a significant minority of HPV-positive OPSCC patients experience treatment failure and have poor outcome; it has been suggested that future clinical investigations concentrate on this group in order to improve outcome (and also to avoid treatment de-intensification in these patients; Adelstein et al, 2009). Currently, there is no widely accepted strategy for the identification of poor prognosis in HPVpositive patients before therapy.

A plausible explanation for the differences in survival between HPV-positive and HPV-negative patients is that virally driven tumours provoke an adaptive immune response directed against tumour-expressed viral antigens: immune responses against the foreign viral antigen are less likely to be suppressed; there is no central immunological tolerance to confound the immune system's attempts to control cancer. HPV-16-specific CD8-positive $\mathrm{T}$ cells have been detected in the blood of HPV-positive OPSCC patients and, more recently, isolated from tumours, implicating a role in the anti-tumour response (Albers et al, 2005; Heusinkveld et al, 2012; Wansom et al, 2012). Several recent studies have further demonstrated anti-tumour immunity in HPV-positive OPSCC. Liang et al (2012) found better survival in HPV-positive patients with seropositivity to E6/E7. Furthermore, infiltration of HPV-positive HNSCC by PD-1-expressing $\mathrm{T}$ lymphocytes has been shown to be a favourable prognostic factor (Badoual et al, 2013).

In several solid tumours, quantification of densities of various T-cell subsets, including $\mathrm{CD}^{+}, \mathrm{CD}^{+}$Treg cells (FoxP3 ${ }^{+}$ $\mathrm{CD}^{+}$), or subset ratios, have been suggested to improve predictive power over that of absolute T-cell number $\left(\mathrm{CD}^{+}{ }^{+}\right.$; Gooden et al, 2011). Cytotoxic $\mathrm{CD}^{+} \mathrm{T}$ cells are the principal anti-tumour effector cells, and their abundance has been shown to be a predictor of positive outcome in several tumour types, particularly colorectal cancer, suggesting that the adaptive immune system has a role in suppressing tumour progression (Galon et al, 2006). Our analysis of a publicly available HNSCC microarray data set showed enrichment of genes associated with $\mathrm{CD} 8{ }^{+} \mathrm{T}$-cell effector function in patients with improved survival, arguing that the $\mathrm{T}$ cells are not simply 'innocent bystanders' of the biological events in the tumour but take an active role in tumour recognition.

We conducted this study to examine the effects of HPV status and TIL levels on survival in OPSCC patients. Similar to other large studies, HPV-positive tumours were associated with significantly improved survival (3-year survival; HPV-positive $82 \%$ vs HPV-negative 56\%, $P<0.001$ ); pathological and clinical features of HPV-positive tumours were consistent with these series. The HPVpositive OPSCC were generally of late stage and were poorly differentiated (both $P<0.001$ ). HPV-positivity inversely correlated with smoking, and with EGFR expression (all $P<0.005$ ). TIL levels also correlated significantly with the HPV status $(P<0.001)$, with around $85 \%$ of HPV-positive OPSCC tumours containing high or moderate levels of TIL. Taking into account the array data, this is likely to reflect an adaptive anti-tumour response as the mechanism for improved outcome. TIL levels stratified HPVpositive OPSCC patients into those with good and poor prognosis.

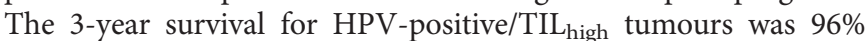
compared with $76 \%$ for HPV-positive/ $\mathrm{TIL}_{\text {mod }}$ and $59 \%$ for $\mathrm{HPV}$ positive/TIL low. The HPV-positive/TIL low tumours had similar survival to HPV-negative tumours (3-year survival, 56\%). We also quantified densities of CD3-, CD4-, CD8-, and FoxP3-positive T cells and carried out ROC analysis to determine the predictive value of cell numbers or subset ratios. These more complex analyses did not outperform the simpler scoring method 
Table 2B. HRs for disease-specific death in OPSCC stratified by HPV status

HPV-positive OPSCC, $n=149$

HPV-negative OPSCC, $n=121$

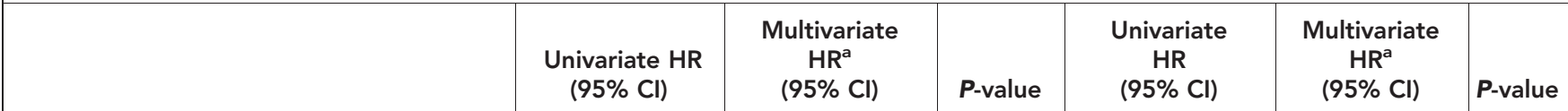

\section{Age}

For each additional year

$1.00(0.97-1.04)$

$1.02(0.98-1.06)$

0.28

1.02 (0.99-1.04)

$1.02(0.99-1.05)$

\section{Gender}

\section{Female}

Male

$1.19(0.50-2.81)$

$0.74(0.26-2.11)$

0.58

$2.06(1.06-4.02)$

$1.70(0.79-3.64)$

\section{Smoking}

Non/ex-smoker/current Smoker $<10$ pack-years

Current smoker $>10$ pack-years

\begin{tabular}{c|c|c|c|c}
1 & 1 & 1 & 1 \\
$5.81(2.38-14.16)$ & $5.80(2.31-14.54)$ & $<0.001$ & $1.37(0.71-2.64)$ & $1.61(0.82-3.16)$
\end{tabular}

\section{Drinking}

\section{Non/ex-drinker}

Current drinker

$0.63(0.23-1.71)$

$0.29(0.08-1.04)$

0.06

\begin{tabular}{c|c}
1 & 1 \\
$0.68(0.31-1.49)$ & $0.54(0.22-1.28)$
\end{tabular}

\section{Stage}

\section{Early (I/II)}

Late (III/IV)

1

$1.93(0.26-14.27)$

\begin{tabular}{l|l|l}
- & - \\
- & -
\end{tabular}

$1.83(0.99-3.37)$

\begin{tabular}{l|l}
- & - \\
- & -
\end{tabular}

\section{T stage}

T1/2

1

$\mathrm{T} 3 / 4$

$3.42(1.61-7.28)$

$3.04(1.28-7.22)$

0.01

\begin{tabular}{c|c}
1 & 1 \\
$1.24(0.71-2.17)$ & $0.98(0.52-1.84)$
\end{tabular}

0.94

Nodal metastases

No

Yes
1

$1.65(0.39-7.00)$

\begin{tabular}{l|l}
- & - \\
- & -
\end{tabular}

\begin{tabular}{c|c}
- & 1 \\
- & $2.13(1.19-3.79)$
\end{tabular}

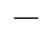

$-$

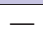

-

\section{N stage}

\section{$\mathrm{NO}-\mathrm{N} 2 \mathrm{a}$}

$\mathrm{N} 2 \mathrm{~b}-\mathrm{N} 3$

1

$2.29(1.00-5.24)$

$1.67(0.67-4.14)$

0.27

\begin{tabular}{c|c}
1 & 1 \\
$2.06(1.20-3.53)$ & $2.15(1.14-4.06)$
\end{tabular}

0.02

\section{Tumour grade}

Well/moderately differentiated

Poorly differentiated

1

$0.74(0.32-1.69)$

$0.74(0.30-1.84)$

0.52

\begin{tabular}{c|c}
1 & 1 \\
$1.58(0.92-2.72)$ & $1.50(0.81-2.81)$
\end{tabular}

0.20

\section{Treatment}

\section{Surgery}

Radiotherapy

Chemoradiotherapy

1
$1.51(0.55-4.15)$
$0.98(0.42-2.31)$

1
$1.01(0.30-3.36)$
$1.02(0.39-2.70)$

\begin{tabular}{l|l}
0.99 \\
0.96
\end{tabular}

\begin{tabular}{c|}
1 \\
$1.64(0.87-3.12)$ \\
$1.48(0.76-2.88)$
\end{tabular}

1
$1.50(0.70-3.22)$
$1.18(0.55-2.57)$

\section{TIL status}

TIL high

TIL moderate

TIL low

\begin{tabular}{|c|}
\hline 1 \\
$2.96(1.11-7.89)$ \\
$5.67(1.96-16.38)$
\end{tabular}

1
$2.47(0.72-8.50)$
$4.86(1.34-17.60)$

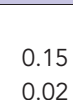

1
$1.39(0.55-3.48)$
$1.71(0.71-4.13)$

$1.71(0.71-4.13)$

1
$1.59(0.54-4.71)$
$2.11(0.73-6.16)$

$2.11(0.73-6.16)$

\section{EGFR}

\section{Negative}

Positive

\begin{tabular}{c|c}
1 & 1 \\
$1.65(0.76-3.62)$ & $1.54(0.63-3.74)$
\end{tabular}

0.34

${ }^{a}$ Multivariate analysis adjusted for age, T stage, $\mathrm{N}$ stage, and smoking status. Patients with no treatment excluded from analysis.

performed on $\mathrm{H}+\mathrm{E}$-stained sections. It is possible that lymphocyte counts performed on randomly selected TMA cores may not be representative of the tumour as a whole. However, TMA cell counts significantly correlated with whole-section TIL levels, arguing against this (e.g., total $\left(\mathrm{CD}^{+}\right)$T-lymphocyte count: $\mathrm{TIL}_{\text {low }} 42.9$, $\mathrm{TIL}_{\text {mod }} 60.4$, and $\mathrm{TIL}_{\text {high }} 96.3, P<0.001$ ).

In keeping with previously published studies (Badoual et al, 2006; Bron et al, 2013), we found that infiltration with 

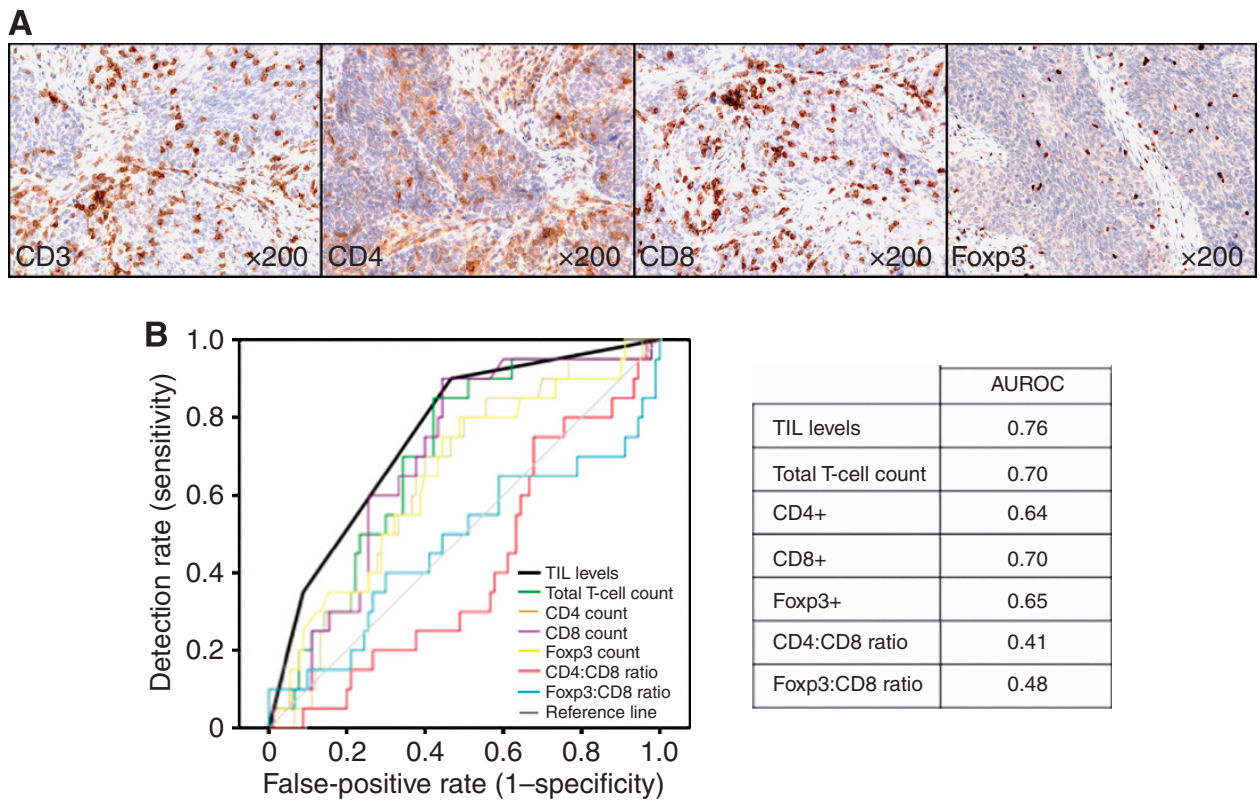

\begin{tabular}{|l|c|}
\cline { 2 - 2 } \multicolumn{1}{c|}{} & AUROC \\
\hline TIL levels & 0.76 \\
\hline Total T-cell count & 0.70 \\
\hline CD4+ & 0.64 \\
\hline CD8+ & 0.70 \\
\hline Foxp3+ & 0.65 \\
\hline CD4:CD8 ratio & 0.41 \\
\hline Foxp3:CD8 ratio & 0.48 \\
\hline
\end{tabular}

Figure 2. Receiver-operating characteristic (ROC) curve for 3-year mortality in HPV-positive OPSCC to determine the predictive value of T-cell number and/or subtype. (A) Immunochemistry showing representative example of an OPSCC stained with T-cell markers (CD3, pan T cells; CD4, helper T cells; CD8 cytotoxic T cells; and FoxP3, regulatory T cells). (B) ROC curve for 3-year HPV-positive OPSCC mortality using TIL levels (scored on $\mathrm{H}+$ E-stained section), compared with cell counts following immunochemistry for T-cell subtypes $\left(\mathrm{CD} 3^{+}, \mathrm{CD}^{+}+\mathrm{CD}^{+}{ }^{+}\right.$, and Foxp3 ${ }^{+}$), including subtype ratios (CD4:CD8, and Foxp3:CD8). Immunochemical quantification did not outperform the simpler scoring method.

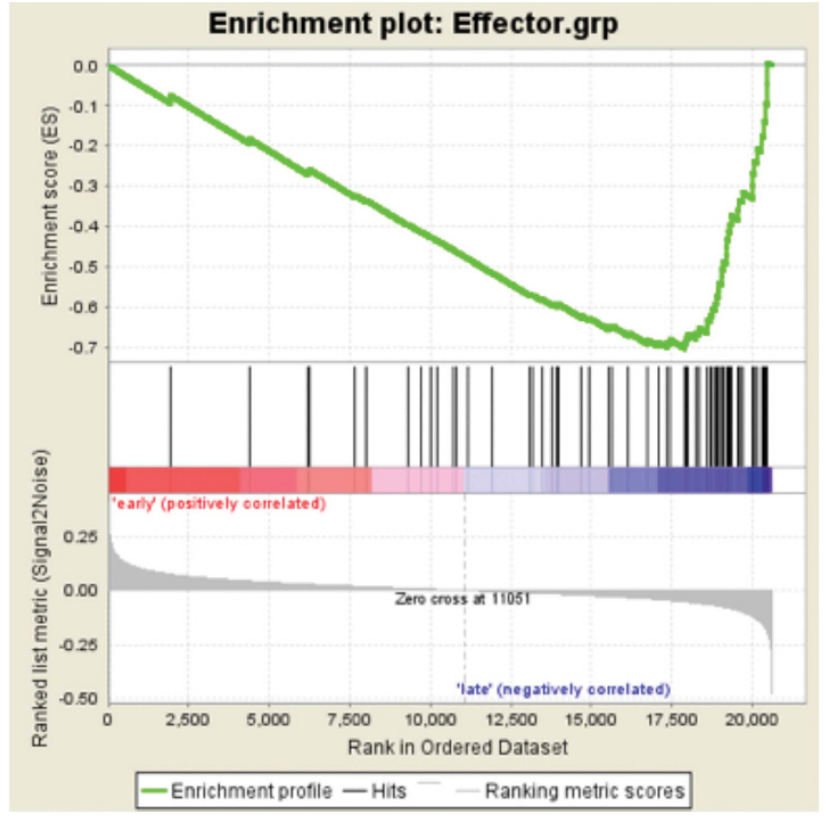

Figure 3. T cell gene-set enrichment in HNSCC. Gene-set enrichment analysis of publicly available gene sets describing effector $C D 8^{+} \mathrm{T}$ cells. Genes to the left and right of the rank-ordered list are enriched in HNSCC patients with early (survival $<3$ years, mean 16 months) or late mortality (survival $>3$ years, mean 49 months), respectively. The rankordered list of genes describing effector CD8 $+\mathrm{T}$ cells is shown in Supplementary Information.

FoxP3-positive regulatory $\mathrm{T}$ cells was associated with improved survival (Figure 2B). However, we feel that the increased numbers seen in HPV-positive tumours simply reflect an increase in overall T-lymphocyte numbers in these tumours. Indeed, the proportion of Foxp3-positive cells was reduced in HPV-positive tumours, compared with those that were HPV-negative (Supplementary
Information). Interestingly, TIL levels did not predict for survival in HPV-negative tumours.

Several studies have reported potential clinical and molecular predictors for identifying poor prognosis in patients with HPVpositive tumours. The HPV-positive light- or non-smokers have the best outcome in OPSCC (Hafkamp et al, 2008; Kumar et al, 2008; Gillison et al, 2012; Sethi et al, 2012). We also found that HPV-positive current heavy smokers had reduced survival benefit compared with non-, ex-, or light smokers (3-year survival; HPVpositive/current heavy smoker $63 \%$ vs HPV-positive/non-, ex-, current light smoker 94\%; Supplementary Information). There was no significant association between heavy smoking and low TIL levels, arguing against TIL levels acting as a surrogate marker for heavy smoking. However, it is possible that poor documentation in retrospective records may be responsible for this lack of correlation, and this should be examined prospectively. We calculated LRs to indicate the strength of a marker (maximising the DR while minimising the FPR). In HPV-positive patients, low TIL levels and smoking status were the best predictors of mortality at 3 years (LRs $3 \cdot 3$ and $2 \cdot 8$, respectively). This was reflected in our prognostic model where, in the 'training' set (UHS patients) only TIL levels, smoking, and T stage were significant (AUROC analysis $0 \cdot 87$ ). When this model was applied to the 'validation set' (PFT/BLT cohort), it was found to be highly predictive (DR $66.7 \%$; FPR $5.6 \%$; LR for 3-year mortality 11.9). This LR is better than other currently used predictive tests. For example, the unrehydrated guaiac fecal occult blood test used in screening for colorectal carcinoma has an LR of 6.4 (DR 64\% and FPR 10\%) (Allison et al, 2007). The 3-year survival of low-risk HPV-positive patients (score $<-0.945$ ) was $94 \%$ compared with $36.8 \%$ for those that were classified as patients with high risk (score $>-0.945, P<0.001$ ).

Ang et al (2010) have suggested a predictive model for HPVpositive OPSCC where patients who are heavy smokers ( $>10$ pack year history) and have advanced nodal disease $(>\mathrm{N} 2 \mathrm{~b})$ are at increased risk of death. We compared this model with our own, and calculated both LRs and 3-year survival rates. The LR for the Ang model in our combined cohort was 4.8 (DR 61.1\% and FPR 
Table 3. LRs for 3-year death from OPSCC

Prognostic values for prediction of death from OPSCC at 3 years

\begin{tabular}{|c|c|c|c|c|c|c|}
\hline & \multicolumn{6}{|c|}{ Prognostic values for prediction of death from OPSCC at 3 years } \\
\hline & \multicolumn{3}{|c|}{ HPV-positive OPSCC } & \multicolumn{3}{|c|}{ HPV-negative OPSCC } \\
\hline & DR \% (21 deaths) & FPR $\%$ (95 alive) & LR & DR \% (41 deaths) & FPR $\%$ (53 alive) & LR \\
\hline \multicolumn{7}{|l|}{ Age, years } \\
\hline $\begin{array}{l}\geqslant 50 \\
\geqslant 55 \\
\geqslant 60\end{array}$ & $\begin{array}{l}57.1 \\
47.6 \\
47.6\end{array}$ & $\begin{array}{l}72.6 \\
51.6 \\
30.5\end{array}$ & $\begin{array}{l}0.79 \\
0.92 \\
1.56\end{array}$ & $\begin{array}{l}85.4 \\
73.2 \\
61.0\end{array}$ & $\begin{array}{l}81.1 \\
58.5 \\
35.8\end{array}$ & $\begin{array}{l}1.05 \\
1.25 \\
1.70\end{array}$ \\
\hline \multicolumn{7}{|l|}{ Gender } \\
\hline Male & 81.0 & 66.3 & 1.22 & 85.4 & 62.3 & 1.37 \\
\hline \multicolumn{7}{|l|}{ Smoking } \\
\hline Smoker $>10 /$ day & 77.8 & 27.9 & 2.78 & 71.4 & 66.7 & 1.07 \\
\hline \multicolumn{7}{|l|}{ Alcohol } \\
\hline Drinker & 72.2 & 86.1 & 0.84 & 75.9 & 87.5 & 0.86 \\
\hline \multicolumn{7}{|l|}{ Stage } \\
\hline $\begin{array}{l}\geqslant \mathrm{II}, \mathrm{III}, \mathrm{IV} \\
\geqslant \mathrm{III}, \mathrm{IV} \\
\text { IV }\end{array}$ & $\begin{array}{r}100.0 \\
95.2 \\
90.5\end{array}$ & $\begin{array}{l}97.9 \\
93.7 \\
76.8\end{array}$ & $\begin{array}{l}1.02 \\
1.02 \\
1.18\end{array}$ & $\begin{array}{l}97.6 \\
80.5 \\
68.3\end{array}$ & $\begin{array}{l}73.6 \\
56.6 \\
41.5\end{array}$ & $\begin{array}{l}1.33 \\
1.42 \\
1.65\end{array}$ \\
\hline \multicolumn{7}{|l|}{ T stage } \\
\hline$>\mathrm{T} 3, \mathrm{~T} 4$ & 57.1 & 23.4 & 2.44 & 43.9 & 28.8 & 1.52 \\
\hline \multicolumn{7}{|c|}{ Nodal metastases } \\
\hline Yes & 95.2 & 88.4 & 1.08 & 78.0 & 45.3 & 1.72 \\
\hline \multicolumn{7}{|l|}{$\mathrm{N}$ stage } \\
\hline$>\mathrm{N} 2 \mathrm{~b}$ & 76.2 & 49.5 & 1.54 & 58.5 & 30.2 & 1.94 \\
\hline \multicolumn{7}{|l|}{ Differentiation } \\
\hline $\begin{array}{l}\text { Moderate, poor } \\
\text { Poor }\end{array}$ & $\begin{array}{l}95.2 \\
66.7\end{array}$ & $\begin{array}{l}98.9 \\
74.7\end{array}$ & $\begin{array}{l}0.96 \\
0.89\end{array}$ & $\begin{array}{r}100.0 \\
53.7\end{array}$ & $\begin{array}{l}98.1 \\
34.0\end{array}$ & $\begin{array}{l}1.02 \\
1.58\end{array}$ \\
\hline \multicolumn{7}{|l|}{ EGFR } \\
\hline Positive & 66.7 & 52.6 & 1.27 & 78.0 & 75.5 & 1.03 \\
\hline \multicolumn{7}{|l|}{ TILs } \\
\hline $\begin{array}{l}\text { Low, moderate } \\
\text { Low }\end{array}$ & $\begin{array}{l}90.0 \\
35.0\end{array}$ & $\begin{array}{l}46.8 \\
10.6\end{array}$ & $\begin{array}{l}1.92 \\
3.30\end{array}$ & $\begin{array}{l}85.4 \\
53.7\end{array}$ & $\begin{array}{l}84.9 \\
41.5\end{array}$ & $\begin{array}{l}1.01 \\
1.29\end{array}$ \\
\hline
\end{tabular}

12.8\%; compared with $\mathrm{LR}=8.6(\mathrm{DR}=70.6 \%$ and $\mathrm{FPR}=8.2 \%)$ using our model) and the 3 -year survival was $91.5 \%$ for low-risk patients and 50\% for high-risk patients (compared with $94 \%$ and $36.8 \%$, respectively, using our model). Clearly, both models have significant predictive power. Interestingly, we found no association between TIL levels and nodal status in HPV-positive OPSCC $(P=0.43)$

Retrospective studies have intrinsic limitations. In this study, cases were excluded if there was insufficient archival material for full pathological and immunochemical analysis. However, demographics and survival of excluded patients did not differ significantly from those included in the study (Supplementary Information). Most patients in this study came from the same geographical area of England, and we cannot therefore assess the effect of geographical, genetic, or ethnic influences on our findings. The number of patients with $\mathrm{HPV}$-positive/ $\mathrm{TIL}_{\mathrm{low}}$ tumours was relatively small and, thus, any conclusions drawn must perhaps be treated with some caution. However, this may simply reflect the fact that the vast majority of HPV-positive tumours are associated with a prominent immune response. Similarly, it could be argued that the heterogenous treatments received by patients in this study complicates the analysis. However, the uniformly improved survival of HPV-positive patients, regardless of treatment modality, argues that the reason for this improved prognosis is related to an intrinsic feature of these tumours. Prospective analysis of our prognostic model will be informative, and a multicentre validation study is currently under development. 

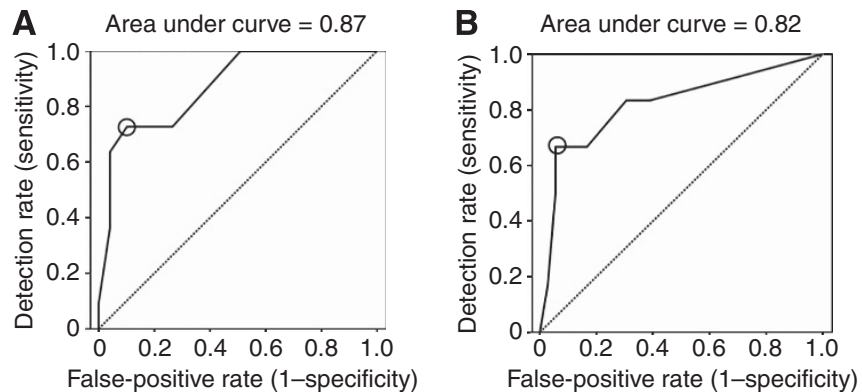

Figure 4. Receiver-operating characteristic (ROC) curves for 3-year HPV-positive OPSCC mortality. (A) ROC curve for 3-year HPV-positive OPSCC mortality derived from the UHS patient cohort (training set) using a model containing TIL levels, smoking, and T stage. The line of no effect is also shown (dashed; area under the curve (AUROC, 50\%). This prognostic model was highly predictive of HPV-positive OPSCC mortality, with an AUROC of 0.87 . A cut-off score of -0.945 was selected (circled in the figure) based on this ROC curve (DR, 72.7\%; FPR ,10.2\%) and applied to the PFT/BLT (test) cohort. (B) ROC curve for 3year HPV-positive OPSCC mortality derived from the PFT/BLT patient cohort (test set) using the predictive model containing TIL levels, smoking, and T stage derived from the UHS training set. The line of no effect is also shown (dashed; (AUROC, 50\%)). The cut-off score of 0.945 identified in the training set is circled in the figure. This score was highly predictive of 3-year mortality (AUROC, 0.82 ), with $66.7 \%$ of dead patients testing positive ( $D R=67 \%)$ and $5.6 \%$ of alive patients testing positive (FPR $=11 \%)$. The resultant LR for prediction of 3 -year mortality was 11.9

In summary, we show that TIL levels predict for survival in OPSCC patients. High TIL levels are significantly associated with HPV status, suggesting that the reason for improved survival in most HPV-positive OPSCC is the presence of an adaptive host anti-tumour immune response. Survival in patients with HPV positive, TIL $_{\text {low }}$ tumours, is not significantly different than in those with HPV-negative disease. A prognostic model based on low TIL levels, heavy smoking, and late $\mathrm{T}$ stage is extremely effective at identifying a group of HPV-positive patients with poor survival. Tumour-infiltrating lymphocyte evaluation can be performed quickly on diagnostic biopsy, and more complex analysis of the T-cell infiltrate does not improve on the predictive power of the simpler scoring method. This is an effective tool for identifying HPV-positive OPSCC patients who are likely to respond poorly to treatment, and is highly relevant for the clinical and pathological evaluation of HPV-positive OPSCC.

\section{ACKNOWLEDGEMENTS}

This study was supported by Cancer Research UK, The Health Foundation, NIHR Cancer Research Network, Royal College of Surgeons (Eng).

\section{CONFLICT OF INTEREST}

The authors declare no conflict of interest.

\section{AUTHOR CONTRIBUTIONS}

Conception and design: MJW, SMT, MM, CW, RS, SH, CHO, EVK, and GJT. Collection and assembly of data: MJW, KS, CR,
AW, CH, NNP, CJR, JP, EVK, and GJT. Provision of study materials or patients: AW, NNP, CJR, HJC, and EVK. Data analysis and interpretation: MJW, SH, GJT, and EVK. Pathological analysis: TM, SJ, KP, and GJT. Manuscript writing: MJW, CHO, EVK, and GJT. Final approval of manuscript: all authors.

\section{REFERENCES}

Adelstein DJ, Ridge JA, Gillison ML, Chaturvedi AK, D’Souza G, Gravitt PE, Westra W, Psyrri A, Kast WM, Koutsky LA, Giuliano A, Krosnick S, Trotti A, Schuller DE, Forastiere A, Ullmann CD (2009) Head and neck squamous cell cancer and the human papillomavirus: summary of a National Cancer Institute State of the Science Meeting, November 9-10, 2008, Washington, D.C. Head Neck 31(11): 1393-1422.

Albers A, Abe K, Hunt J, Wang J, Lopez-Albaitero A, Schaefer C, Gooding W, Whiteside TL, Ferrone S, DeLeo A, Ferris RL (2005) Antitumor activity of human papillomavirus type $16 \mathrm{E} 7$-specific T cells against virally infected squamous cell carcinoma of the head and neck. Cancer Res 65(23): $11146-11155$

Allison JE, Sakoda LC, Levin TR, Tucker JP, Tekawa IS, Cuff T, Pauly MP, Shlager L, Palitz AM, Zhao WK, Schwartz JS, Ransohoff DF, Selby JV (2007) Screening for colorectal neoplasms with new fecal occult blood tests: update on performance characteristics. J Natl Cancer Inst 99(19): 1462-1470.

Ang KK, Harris J, Wheeler R, Weber R, Rosenthal DI, Nguyen-Tan PF, Westra WH, Chung CH, Jordan RC, Lu C, Kim H, Axelrod R, Silverman CC, Redmond KP, Gillison ML (2010) Human papillomavirus and survival of patients with oropharyngeal cancer. N Engl J Med 363(1): 24-35.

Badoual C, Hans S, Merillon N, Van Ryswick C, Ravel P, Benhamouda N, Levionnois E, Nizard M, Si-Mohamed A, Besnier N, Gey A, Rotem-Yehudar R, Pere H, Tran T, Guerin CL, Chauvat A, Dransart E, Alanio C, Albert S, Barry B, Sandoval F, Quintin-Colonna F, Bruneval P, Fridman WH, Lemoine FM, Oudard S, Johannes L, Olive D, Brasnu D, Tartour E (2013) PD-1-expressing tumor-infiltrating T cells are a favorable prognostic biomarker in HPV-associated head and neck cancer. Cancer Res 73(1): 128-138.

Badoual C, Hans S, Rodriguez J, Peyrard S, Klein C, Agueznay Nel H, Mosseri V, Laccourreye O, Bruneval P, Fridman WH, Brasnu DF, Tartour E (2006) Prognostic value of tumor-infiltrating CD4 + T-cell subpopulations in head and neck cancers. Clin Cancer Res 12(2): 465-472.

Best JA, Blair DA, Knell J, Yang E, Mayya V, Doedens A, Dustin ML, Goldrath AW (2013) Transcriptional insights into the CD8 ++ ) T cell response to infection and memory T cell formation. Nat Immunol 14(4): 404-412.

Bron L, Jandus C, Andrejevic-Blant S, Speiser DE, Monnier P, Romero P, Rivals JP (2013) Prognostic value of arginase-II expression and regulatory T-cell infiltration in head and neck squamous cell carcinoma. Int $J$ Cancer 132(3): E85-E93.

Chaturvedi AK, Engels EA, Pfeiffer RM, Hernandez BY, Xiao W, Kim E, Jiang B, Goodman MT, Sibug-Saber M, Cozen W, Liu L, Lynch CF, Wentzensen N, Jordan RC, Altekruse S, Anderson WF, Rosenberg PS, Gillison ML (2011) Human papillomavirus and rising oropharyngeal cancer incidence in the United States. J Clin Oncol 29(32): 4294-4301.

D'Souza G, Kreimer AR, Viscidi R, Pawlita M, Fakhry C, Koch WM, Westra WH, Gillison ML (2007) Case-control study of human papillomavirus and oropharyngeal cancer. N Engl J Med 356(19): 1944-1956.

Dayyani F, Etzel CJ, Liu M, Ho CH, Lippman SM, Tsao AS (2010) Meta-analysis of the impact of human papillomavirus (HPV) on cancer risk and overall survival in head and neck squamous cell carcinomas (HNSCC). Head Neck Oncol 2: 15.

Deeks JJ, Altman DG (2004) Diagnostic tests 4: likelihood ratios. BMJ 329(7458): 168-169.

Fakhry C, Westra WH, Li S, Cmelak A, Ridge JA, Pinto H, Forastiere A, Gillison ML (2008) Improved survival of patients with human papillomavirus-positive head and neck squamous cell carcinoma in a prospective clinical trial. J Natl Cancer Inst 100(4): 261-269.

Galon J, Costes A, Sanchez-Cabo F, Kirilovsky A, Mlecnik B, Lagorce-Pages C, Tosolini M, Camus M, Berger A, Wind P, Zinzindohoue F, Bruneval P, Cugnenc PH, Trajanoski Z, Fridman WH, Pages F (2006) Type, density, and location of immune cells within human colorectal tumors predict clinical outcome. Science (New York, NY) 313(5795): 1960-1964. 
Gillison ML, Zhang Q, Jordan R, Xiao W, Westra WH, Trotti A, Spencer S, Harris J, Chung CH, Ang KK (2012) Tobacco smoking and increased risk of death and progression for patients with p16-positive and p16-negative oropharyngeal cancer. J Clin Oncol 30(17): 2102-2111.

Gooden MJ, de Bock GH, Leffers N, Daemen T, Nijman HW (2011) The prognostic influence of tumour-infiltrating lymphocytes in cancer: a systematic review with meta-analysis. Br J Cancer 105(1): 93-103.

Granata R, Miceli R, Orlandi E, Perrone F, Cortelazzi B, Franceschini M, Locati LD, Bossi P, Bergamini C, Mirabile A, Mariani L, Olmi P, Scaramellini G, Potepan P, Quattrone P, Ang KK, Licitra L (2012) Tumor stage, human papillomavirus and smoking status affect the survival of patients with oropharyngeal cancer: an Italian validation study. Ann Oncol 23(7): 1832-1837.

Hafkamp HC, Manni JJ, Haesevoets A, Voogd AC, Schepers M, Bot FJ, Hopman AH, Ramaekers FC, Speel EJ (2008) Marked differences in survival rate between smokers and nonsmokers with HPV 16-associated tonsillar carcinomas. Int J Cancer 122(12): 2656-2664.

Heagerty PJ, Lumley T, Pepe MS (2000) Time-dependent ROC curves for censored survival data and a diagnostic marker. Biometrics 56(2): 337-344.

Heusinkveld M, Goedemans R, Briet RJ, Gelderblom H, Nortier JW, Gorter A, Smit VT, Langeveld AP, Jansen JC, van der Burg SH (2012) Systemic and local human papillomavirus 16 -specific T-cell immunity in patients with head and neck cancer. Int J Cancer 131(2): E74-E85.

Hong A, Dobbins T, Lee CS, Jones D, Jackson E, Clark J, Armstrong B, Harnett G, Milross C, O'Brien C, Rose B (2010a) Relationships between epidermal growth factor receptor expression and human papillomavirus status as markers of prognosis in oropharyngeal cancer. Eur J Cancer 46(11): 2088-2096.

Hong AM, Dobbins TA, Lee CS, Jones D, Harnett GB, Armstrong BK, Clark JR, Milross CG, Kim J, O’Brien CJ, Rose BR (2010b) Human papillomavirus predicts outcome in oropharyngeal cancer in patients treated primarily with surgery or radiation therapy. $\mathrm{Br} J$ Cancer 103(10): 1510-1517.

Kumar B, Cordell KG, Lee JS, Worden FP, Prince ME, Tran HH, Wolf GT, Urba SG, Chepeha DB, Teknos TN, Eisbruch A, Tsien CI, Taylor JM, D’Silva NJ, Yang K, Kurnit DM, Bauer JA, Bradford CR, Carey TE (2008) EGFR, p16, HPV Titer, Bcl-xL and p53, sex, and smoking as indicators of response to therapy and survival in oropharyngeal cancer. J Clin Oncol 26(19): 3128-3137.

Lassen P, Eriksen JG, Hamilton-Dutoit S, Tramm T, Alsner J, Overgaard J (2009) Effect of HPV-associated p16INK4A expression on response to radiotherapy and survival in squamous cell carcinoma of the head and neck. J Clin Oncol 27(12): 1992-1998.

Liang C, Marsit CJ, McClean MD, Nelson HH, Christensen BC, Haddad RI, Clark JR, Wein RO, Grillone GA, Houseman EA, Halec G, Waterboer T, Pawlita M, Krane JF, Kelsey KT (2012) Biomarkers of HPV in head and neck squamous cell carcinoma. Cancer Res 72(19): 5004-5013.

Licitra L, Perrone F, Bossi P, Suardi S, Mariani L, Artusi R, Oggionni M, Rossini C, Cantu G, Squadrelli M, Quattrone P, Locati LD, Bergamini C, Olmi P, Pierotti MA, Pilotti S (2006) High-risk human papillomavirus affects prognosis in patients with surgically treated oropharyngeal squamous cell carcinoma. J Clin Oncol 24(36): 5630-5636.

Marsh D, Suchak K, Moutasim KA, Vallath S, Hopper C, Jerjes W, Upile T, Kalavrezos N, Violette SM, Weinreb PH, Chester KA, Chana JS, Marshall JF,
Hart IR, Hackshaw AK, Piper K, Thomas GJ (2011) Stromal features are predictive of disease mortality in oral cancer patients. J Pathol 223(4): 470-481.

McShane LM, Altman DG, Sauerbrei W, Taube SE, Gion M, Clark GM (2005) REporting recommendations for tumour MARKer prognostic studies (REMARK). Br J Cancer 93(4): 387-391.

Robinson M, Sloan P, Shaw R (2010) Refining the diagnosis of oropharyngeal squamous cell carcinoma using human papillomavirus testing. Oral Oncol 46(7): 492-496.

Royston P, Moons KG, Altman DG, Vergouwe Y (2009) Prognosis and prognostic research: developing a prognostic model. BMJ 338: b604.

Sethi S, Ali-Fehmi R, Franceschi S, Struijk L, van Doorn LJ, Quint W, Albashiti B, Ibrahim M, Kato I (2012) Characteristics and survival of head and neck cancer by HPV status: a cancer registry-based study. Int $J$ Cancer 131(5): 1179-1186.

Termine N, Panzarella V, Falaschini S, Russo A, Matranga D, Lo Muzio L, Campisi G (2008) HPV in oral squamous cell carcinoma $v$ s head and neck squamous cell carcinoma biopsies: a meta-analysis (1988-2007). Ann Oncol 19(10): 1681-1690.

Thurlow JK, Pena Murillo CL, Hunter KD, Buffa FM, Patiar S, Betts G, West CM, Harris AL, Parkinson EK, Harrison PR, Ozanne BW, Partridge M, Kalna G (2010) Spectral clustering of microarray data elucidates the roles of microenvironment remodeling and immune responses in survival of head and neck squamous cell carcinoma. J Clin Oncol 28(17): 2881-2888.

Uppaluri R, Dunn GP, Lewis Jr JS (2008) Focus on TILs: prognostic significance of tumor infiltrating lymphocytes in head and neck cancers. Cancer Immun 8: 16.

Wansom D, Light E, Thomas D, Worden F, Prince M, Urba S, Chepeha D, Kumar B, Cordell K, Eisbruch A, Taylor J, Moyer J, Bradford C, D'Silva N, Carey T, McHugh J, Wolf G (2012) Infiltrating lymphocytes and human papillomavirus-16-associated oropharyngeal cancer. Laryngoscope 122(1): 121-127.

Wansom D, Light E, Worden F, Prince M, Urba S, Chepeha DB, Cordell K, Eisbruch A, Taylor J, D'Silva N, Moyer J, Bradford CR, Kurnit D, Kumar B, Carey TE, Wolf GT (2010) Correlation of cellular immunity with human papillomavirus 16 status and outcome in patients with advanced oropharyngeal cancer. Arch Otolaryngol Head Neck Surg 136(12): 1267-1273.

Westra WH, Taube JM, Poeta ML, Begum S, Sidransky D, Koch WM (2008) Inverse relationship between human papillomavirus-16 infection and disruptive 553 gene mutations in squamous cell carcinoma of the head and neck. Clin Cancer Res 14(2): 366-369.

Worden FP, Kumar B, Lee JS, Wolf GT, Cordell KG, Taylor JM, Urba SG, Eisbruch A, Teknos TN, Chepeha DB, Prince ME, Tsien CI, D'Silva NJ, Yang K, Kurnit DM, Mason HL, Miller TH, Wallace NE, Bradford CR, Carey TE (2008) Chemoselection as a strategy for organ preservation in advanced oropharynx cancer: response and survival positively associated with HPV16 copy number. J Clin Oncol 26(19): 3138-3146.

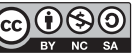
This work is licensed under the Creative Commons Attribution-NonCommercial-Share Alike 3.0 Unported License. To view a copy of this license, visit http://creativecommons. org/licenses/by-nc-sa/3.0/

Supplementary Information accompanies this paper on British Journal of Cancer website (http://www.nature.com/bjc) 